\title{
Discussion: The vicarage farm incident - a precautionary tale
}

Dennis Gedge BSC(Eng), CEng, MICE, MCInstCES

Consulting Engineer, Newton Poppleford, Devon, UK

(dennisgedge@btinternet.com)

The author has reminded us of some of the philosophical questions which surround the profession of civil engineering. These questions have received academic study, they do not appear in the mainstream of civil engineering, but they are important. Engineering has been described as philosophically weak (Mitcham, 2008). Medicine and the law on the other hand have been seen as philosophically strong.

The profession of civil engineering is scattered within an industry, its relationship with the public is therefore vague.

The pandemic of 2020 has thrown into sharp relief the question of whether or not the dangers from physical things are the province of the law or of science.

Turning to civil engineering, which is intertwined with politics, things are more complicated. Opinion is divided - that is, should civil engineers actively take part in politics, or should politicians be more educated in engineering because the modern world relies so heavily on things of technology?

The safety of civil engineering artefacts is regulated by the law of the land. Legislators define laws by majority voting. However, whether or not physical things will collapse, catch fire, be swept away by floods or fail in other ways is governed by the absolute laws of nature, and those laws have inevitable consequences if they are not followed.

The aims of the Robens Commission in 1970 were quite clear; it attempted to shift responsibility for safety in construction to those causing the actual risks to manage them, rather than just setting prescriptive rules for others to follow. Much progress has been made since then, accidents, injuries and deaths resulting from all kinds of failures in civil engineering are now far fewer, and attitudes and a general respect of danger by all involved have also improved. However, human nature being what it is means that things haven't quite worked out as hoped, because safety is now seen almost as a separate subject, with its own experts. The conundrum we have is that safety experts may indeed be well qualified to tell us if a planned procedure complies with the law, but they cannot tell us whether or not a weakened or poorly designed or constructed dam such as the one at the Vicarage reservoir is liable to collapse.
Safety officers are only concerned with man-made rules; civil engineers on the other hand have ideas and some understanding about how some of the forces of nature work, and this is much more relevant.

The standing of a profession in the eyes of the public is interwoven with social moirés, and possibly the civil engineering profession is now too entrenched within its industry for it to be generally recognised by the public. Presidents of the Institution of Civil Engineers often refer to their industry; the $\mathrm{BBC}$ refers to the New Civil Engineer as the trade magazine of the civil engineering industry.

On the other hand, there is a change in the public perception of professional engineers. The tragic collapse of the Polcevera viaduct at Genoa has now seen calls for engineering assessments of structures by independent professional engineers free of industrial or corporate attachments. The safety of things like this must be looked at independently.

It is sad that many reforms in engineering only come about as a result of disaster, and civil engineering has the additional challenge of only being able to exist if projects are economically viable.

One would have hoped that the Reservoirs Act of 1975 (HMG, 1975) put civil engineers firmly in control with regard to dam safety, but police, farmers and landowners are members of the public, and they will tend to stand in awe of the law, rather than taking the advice of a civil engineer when they are standing on the downstream slope of an unstable dam. They are similar to those who think a tree with a preservation order placed on it is prevented in some way from being blown down in a gale.

The civil engineering profession therefore should seek a different relationship with those in charge of safety. In other words it doesn't so much matter whether a thing is legal or not, what matters is: is it safe?

\section{REFERENCES}

HMG (Her Majesty's Government) (1975) Reservoirs Act 1975. The Stationery Office, London, UK.

Mitcham CA (2008) Workshop on Philosophy and Engineering. Royal Academy of Engineering, London, UK. 